\title{
Workforce Management Practices: Evolution through
}

\author{
Ages \\ Dr. Arun Kumar \\ Associate Professor, Department of Commerce and Business Administration, University of \\ Allahabad, Allahabad, India \\ Email: arun@shuchita.com \\ Priyadarshani Singh (Corresponding Author) \\ Research Scholar, Department of Commerce and Business Administration, University of \\ Allahabad, Allahabad, India \\ Email: priyadarshanisingh.delhi@gmail.com
}

Doi:10.5296/ijhrs.v3i4.4786 URL: http://dx.doi.org/10.5296/ijhrs.v3i4.4786

\begin{abstract}
Management of today is relatively at liberty to concentrate on higher business issues, as the information age has bestowed them with advanced solutions of workforce management. This age is capitalizing on automated and integrated workforce management and optimization solutions. Not only has it eased the workforce management process but has also transformed the workforce management practices. It has transformed all the aspects of managing the complete workforce lifecycle. Workforce management has travelled a long journey.

The enigmas of workforce management can be unfold by exploring the workforce management from the very beginning. What were the workforce management practices in preceding ages, how did they evolve?

This paper analyses the four ages of civilization - hunter and gatherers (foragers), agrarians, industrial and information for workforce management functions with the lens of evolution. The paper intends to understand the evolutionary pattern of workforce management in order to align the practices in line with need of the day, and find a path to understand the future course, in approach and practice.
\end{abstract}

Keywords: Workforce Management, Information Age, Industrial Age, Agrarian Age, Foragers.

\section{Introduction}

Wherever we start from - bands, kingdoms, or democracies, traditionalists, boomers, gen $\mathrm{x}$ or millennials, there has always been workforce. They are just not the evidences of changing times, economies or technologies but more the evidence of changing paradigms, beliefs, attitudes, practices and values. 
From the time when the band lynches its member for not following the rules of the band, and today when karoshi takes place. What changes happened with principles? From the time, a king recognized as living God on the earth, to the time customer is king, how values transformed.

"Spinning Jenny and Water Frame (1960s) for the first time made man, who used to clock with the sun, to show up by factory clocks"1, and, he is the one today who is heading towards sublimating the difference of day and night, quadrant and culture. What has changed? Are they transportation and communication only or is an intrinsic shift of outlook?

"Amazon.com made headlines this week with the announcement of Amazon Prime Air, but it isn't the only company that's testing delivery drones. Reports this week say UPS and Google are two other companies that are also testing delivery drones for their services."2 From horse cart to Amazon and Google fighting to use drone and robots to deliver goods to customers, haven't the workforce and workforce management passed through caverns and flies?

"People can be given something in an external way that they cannot yet grasp in their hearts and mind. Things may come to them in the form of a tradition or through the written word." 3 The purpose of this paper is to explore the heartfelt meaning of workforce and workforce management in the arena of the concomitant age - the information age, in contrast staining with the preceding age - the industrial age, not for the extrinsic symptoms of pace, restructuring, and sufficiency but the intrinsic shifts of principles, values, and practices.

\section{What is Workforce Management?}

A new era of innovation in workforce management is upon us with hoards of workforce management solution offers, claiming to manage all the activities needed to maintain a productive workforce.

To understand workforce management, it is crucial to understand workforce and management, first discretely, and then jointly.

As per Oxford Dictionary, workforce is the people engaged in or available for work, either in a country or area or in a particular firm or industry. Workforce is the pool of labor working for a company, an industry or a country.

Management has traces in literature from the olden time - Arthshastra by Kautilya (300BC), The Prince by Niccolò Machiavelli (16 ${ }^{\text {th }}$ Century), The Wealth of Nations by Adam Smith (18 ${ }^{\text {th }}$ Century). $19^{\text {th }}$ century developed the elements of technical production while $20^{\text {th }}$ century was the era of scientific management. $21^{\text {st }}$ century's management is renovating into leadership as workplace control turns into workplace democracy.

Management is "the organization and coordination of the activities of a business in order to achieve defined objectives." As Harold Koontz says, Management is the art of getting things done through others and with formally organized groups; the management finds neutral meaning as this has been the one permanent feature of 


\section{Ml Macrothink}

management through ages. The accepted grassroots notion of management is getting the work done and to succeed in achieving by directing and coordinating other people, things, and situations.

There are two things, the one is workforce, and the other is management. They are the two components who actively run business, nothing other. They are the analogically distinguishable as the head, and the rest of the body. The workforce works in various capacities like different body parts and the management coordinates and plans the moves. Therefore, workforce management is, basically, the aspect of running an organization where management is controlling the results by organizing and harmonizing the workforce using various concurrent tools, means, and concepts.

Workforce management has been defined in various ways. Calvert narrates- "I have never found an official definition of workforce management, but in practice it is a term usually used to differentiate between the basic practice of scheduling staff, and using an integrated set of tools and processes to cover all aspects of managing staff."5 BusinessDictionary.com defines workforce as "After employees have been hired, the "workforce" needs to be managed so that they know what to work on. Typical areas of focus include scheduling employees work hours, planning work responsibilities and duties, working as team, and tracking results of the work efforts. Also called employee relationship management." 6

Workforce management is the practice where the management manages the workforce, keeping other aspects of business in parallel, and the objective of the business in center, with the intent of workforce optimization.

Specifically, workforce management includes

1. Analysis of work

2. Forecasting and scheduling

3. Designing jobs

4. Talent acquisition

5. Time, attendance and absence management

6. Compensation and benefits

7. Administration of workforce (work and culture discipline)

8. Performance management

9. Career and succession planning

10. Learning and training management

In fact, workforce management has been transforming time to time to fit in with the flow of the dominant stretches of the eras. We are considering the above mentioned ten points as valid parameters to study four ages. These points are considered as pillars of comparative exploration of workforce management in different ages, as explained in advent text.

\section{Information Age}

There is no universally accepted model to breakup the history into stages. Humanity grew at its pace with the fruition forces of passing times. "It would be unreasonable to expect 


\section{Macrothink

the ethical and unreasonable development of a mature civilization in a young and vigor one, as it would be to expect the wisdom and otherworldliness of an aged individual in a spirited, pleasure seeking young man." ${ }^{, 7}$, so does the evolution of mankind from animal to present advancement.

Here, for the purpose, the stages of human development is seen through five periods:

1. Old Stone Age (Paleolithic Period)

2. New Stone Age (Neolithic Period)

3. Bronze Age

4. Iron Age

5. Industrial Age

6. Information Age

In Old Stone Age, people were hunting and surviving like higher order animals. In the new stone age, the man discovered agriculture, so in other view, we see the stages as:

1. Hunting and Gathering

2. Agriculture

3. Industrial

4. Information

We are living in information age, also known as Computer Age, Digital Age, and New Media Age. "The Information Age. That is what many pundits, writers and analysts have already labeled these concluding years of the twentieth century and the beginning of the $21^{\text {st }}$ century." 8 To be precise, "In the 1970 s, the developed world entered into a new age, one of information." $" 9$

For the producer/service provider, the information age is one where the horizontally networked, highly interconnected, less hierarchical, less command and control oriented organizations replaced vertically integrated, command and control, hierarchically structured organizations. The big data is the key basis of competition, underpinning new waves of growth, and innovation. Information technology is the age of hyper-specialization - better, faster and cheaper.

For consumer, the information age is one, where he is going to be engaged and driven by the information that he is not aware about himself. "Recommendation engines are everywhere - telling you what to eat, what to buy and these are getting smarter and smarter based on algorithms that figure out your behavior and spit out what is relevancy." 10

No society completely vanishes the preceding society, rather it keeps appends of preceding times. Forager, agricultural or industrial all epochs are living over this earth in information age with the pioneers of wisdom age. However, lot has been written about visions about the $21^{\text {st }}$ century, petite has been spent upon echoes of the past. "It seems appropriate at the juncture of two centuries to take a few precious moments to reflect not only the direction we are going, but also more importantly to reflect upon where we have been." 11 
"Hunting and Gathering was humanity's first and most successful adaptation, occupying at least 90 percent of human history. Until 12,000 years ago, all humans lived this way.""12 This adaptation attribute of man, voyaged through agrarian, then industrial ages, reached information age. Nolan, in his case study, very aptly describes the sorts of presence of information age, "IT industry operates on internet time rather than in budget years-using the equivalence of a dog's life span with a human's: that is supposedly 6 or 7 dog years equals one human year." ${ }^{\prime 3} \mathrm{He}$ further presents graphical transformational process of moving from industrial age management principles to information age management principles, as follows:

\section{Transition to the Information Economy Management Model:}

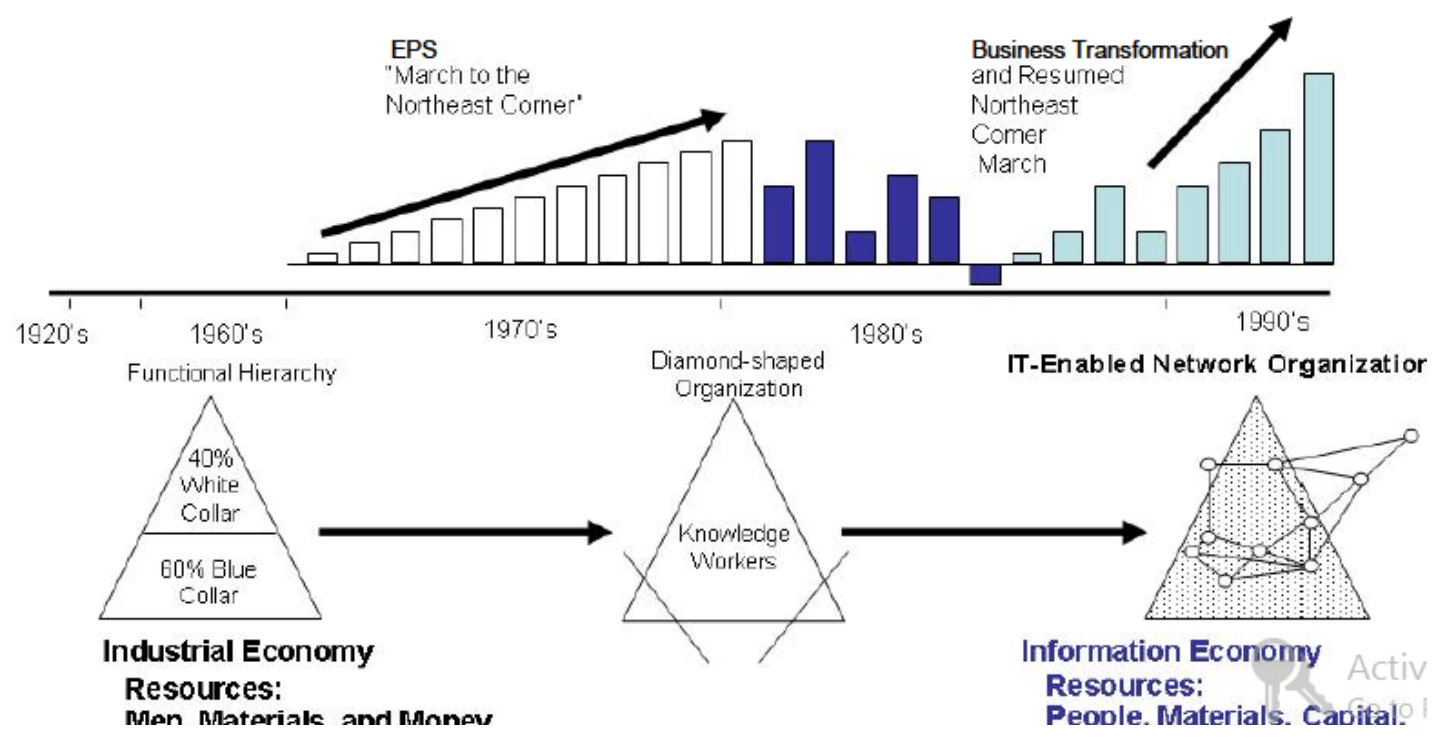

Fig. 1: Transition to the Information Economy Management Model $^{14}$

Information age is possible because of information system capabilities. The information system capabilities - performing high speed, high volume and numerical computations are in a position to support the six business objectives: ${ }^{15}$

1. Improving Productivity

2. Reducing costs

3. Improving decision making

4. Facilitating Collaboration

5. Enhancing customer relationships

6. Developing new strategic applications

\section{Workforce Management Practices in Different Ages}

Practice is the actual application or use of an idea, belief, or method, as opposed to theories relating to it. 
Here is presented, how workforce management practices were different in different ages:

Analysis of work in foragers' (hunter and gatherers') time, in the beginning, was for one day, the today. The practice was egalitarian, they used to hunt and gather to consume the food in a day or two after they procure it by intake and gifting. In later stages they started Non-egalitarian practices - storing the surplus food. They started looking towards work as an activity for tomorrow as well and thus started planning ahead in that direction.

Agrarians got involved in forest gardening and also started understanding the seasonal demands and produces. Agrarian people started practicing the responsibility of production. Their lives were moving around the demands of domesticated flora and fauna. The knowledgeable head of the family used to make analysis and delegate the tasks to all the family members. They started practicing hard in the fields.

In industrial age division of work and scientific management came. Workforce management shouldered analyzing the work scientifically and dividing the labor accordingly.

Information age is the age of specialized outsourcing and networking, and the work is analyzed from the very angle.

Forecasting and scheduling was hardly in practice by foragers. They had ample time to reach their goal as basically they were exploring the natural laws of life. Their needs were only food and bare minimum shelter and the time of forecasting and scheduling had not arrived to them.

Agrarians, as started an agricultural and pastoral life, had to respond on time to their fields and cattle. They gradually learnt forecasting and scheduling the tasks informally and with human considerations.

The industrial age brought formal forecasting and scheduling of tasks and proper monitoring systems with little human considerations. The machine became man's identity for he had to perform in tandem with the production capability of machine schedules based on forecast.

Information age is empowered by the information technology infrastructure and the work schedules and escalates like never before. The work is divided into teams with different specializations working from different places, one team's output is the input for other team so every team has to go by the forecast and schedule to reach efficiency. Project management applications, ERP and many other softwares, and groupwares are the sharp facilitator of work.

Designing jobs in pre-agrarian age has no traces. Basically there were handful of jobs like gathering edible foodstuff, hunting, roasting the quarry, rearing children, preparing some craft, worshipping, singing, dancing and fighting which foragers used to learn gradually by doing with elders.

In agrarian times, as the task of cropping is big and follows natural principle of flow of time, people understood the agriculture as process and started delegating tasks to other family and clan members with instructions about what and how they are supposed to do. Jobs were not designed per se but the minds were clear about the repetitive process with the incorporated nuances.

Concept of job design is the offspring of industrial age where job has to be designed in order to get maximum productivity with fixed duties and responsibilities and the methods of doing the job and thus finding the most suitable incumbent who can do it. 
In information age, the practice is to conform to the scenario of global labor, information infrastructure and information paradigm of business structures. As the new knowledge based jobs are in place with positive employment growth and global employment trends, the job is designed with the focus on objectives in place of duties and responsibilities resulting into big shifts in working time, job stability, location and employer-employee contract.

"Talent acquisition is the process of finding and acquiring skilled human labor for organizational needs and to meet any labor requirement." 16 The forbearing outlook of foragers narrowed them only to their bloodline and offered only the limited and fated talent. There was no scope, no idea of talent acquisition.

As agriculture age developed, the knack of vegetation of domesticated plants and animals became prime key of living. Sociable communities used to learn from each other and exchange labor as per their needs. The society was in the frame of cast system so the limited opportunities were present for talent acquisition.

Industrial age changed the meaning of job. No particular skill was required to operate many of the new factory machines, the workers were considered unskilled. The practice of talent acquisition, for white collars was Darwinism, and for blue collars rugged individualism. The value was not the economy but the cheapness.

Information age is the best time so far for talent acquisition with the emergence of time-critical tasks. It is the age of web-enabled intermediaries, where talent is judged by what they produce, not by resume, experience or other things. The practice is atomization - many workers doing pieces of a single job with hyper-specialization.

Time, attendance and absence management were, in principle, far away, in hunter and gatherers, though the small bands used to perform together and they required to be at the same place at the same time. The bands used to be together, the practice was to do one's own portion and coordinate with others for egalitarian benefits.

In agrarian age, man started exercising choice for results so he was bound to perform accordingly. Time and attendance got relevance. The practice was to compensate.

Industrial era was the time of mechanical time card clock, manual time and attendance methods. The practice was clock.

Information age attendance softwares and devices on ERP, integrated with the system, provide workforce management customizable timetables, scheduling, and employee record etc. and as the focus is shifting more towards productivity than working hours, the time and attendance are becoming old hat.

Compensation and benefits were just in the form of proportionate distribution of quarry and other gathered foodstuff in the pre-agrarian era. The responsibility of the head was to avail eating, mating and safekeeping to band members. Women used to appreciate the meat brought back to camp by men.

In agrarian age, man turned into producer in place of a consumer. This was a big shift. The arduous work was compensated with the produce of choice. The practice was to strike for more independence with more hands to have enough to make exchanges to buy varied commodities.

In industrial era, man became the part of big production machineries. He started earning currency for the labor which he started using to buy commodities produced by such big 
machineries. The compensation and benefits concept got momentum. The practices were exploitation.

Information age, compensation and benefits are directly proportional to the contribution. HRIS tools are providing organizations measures of contribution in all aspects to create transparent system. The practice is realizing compensation objectives and individual equity.

Administration of workforce (work culture and discipline) were very rudimentary and astringent, everyone in the group has to conform to the beliefs and practices of the band. The practice of administration was imposition of practices.

Agrarians were tightly disciplined community. The practice was taking charge of deliverables of the community with certain cultural strictures.

Industrial age administration of work was pitiable, men, women and children all were facing inhuman conditions which resulted into labor riots. The practice was to force workers for the business interests.

Concept of workforce administration is evaporating in the information age, it is fraternizing with talent management because of blooming trend of crowdsourcing.

Performance management was abysmal to foragers.

Agriculture agers started passing the knowledge in more formal manner to the next generation and thus emerged the rudimentary method of performance management in the form of ensuring that the next generation is able to perform well in cultivating domesticated crops and the associated nuances explored yet.

Performance measurements were not linked to causation in industrial age. There was low motivation for professionalism or quality, the workforce were just thrown in the furnace of mandates to work for 12 to 16 hours in abject work conditions. The practice was measurement.

The digital era is the era of performance management, ongoing investments are made for performance management not the measurement. Smart objectives and feedback give open environment for performance. The practice is culture of performance.

Career and succession planning used to exist as prospect not plan in pre-agrarian age. Persons used to take initiative at any one time depended on the task being performed, moreover, it was jungle period. The practice was survival of the fittest and honing the spirited bloodline.

Agrarians had mental inventory of talents that they need to sharpen and uphold for future. They acknowledged the individual talents associated with multiple husbandry tasks, though, the notion of career was not developed. When farmers became capable of producing food beyond the needs of their own families, others in their society were freed to devote themselves to projects other than food production and acquisition. The practice was to promote talents for livelihood and civilization.

A turnaround took place with industrial revolution in the nature of jobs. The fundamentals of work changed. It was all chaos turning around the basic necessities of life like food, house and cloth in the newbie urban setup. Only white collars had limited opportunities. Career was the buzzword. The practice was scientific utilization of labor.

Digital era is the time of atomized and specialized working, the time for organizations to shed 
extra load by distributing computer-based jobs. New class of intermediaries are rising that connect enterprises with super-specialized workers. The practice is collaboration.

Learning and training management, as concepts, were nowhere amongst foragers and agrarians.

In agriculture age, learning and trainings were imparted on the job, and sometimes, formally by learned ones. The family was a focal point in learning and training, and children were able to perceive and participate in almost all productive activities. The practice was, basically, imparting the known.

In industrial era, household lost its capability to provide training and manage learning as the factories became the center of work. The transfer of knowledge to next generation stopped. There was less time and slenderer opportunities for learning. The practice was clock and machine.

The capital of information age is the knowledge, blue collar jobs are automated and white collar jobs turned into knowledge work. Learning and training are pivotal in digital age. The practice is creating and subscribing knowledge networks.

The brief insight of exploration of practices can be beheld as:

\begin{tabular}{|c|c|c|c|c|c|}
\hline \multirow[t]{2}{*}{ No. } & \multirow{2}{*}{$\begin{array}{l}\text { Workforce } \\
\text { Management } \\
\text { Areas }\end{array}$} & \multicolumn{4}{|l|}{ Practices } \\
\hline & & $\begin{array}{l}\text { Hunter and } \\
\text { Gatherers }\end{array}$ & Agrarians & Industrial & Information \\
\hline 1 & $\begin{array}{l}\text { Analysis of } \\
\text { work }\end{array}$ & $\begin{array}{l}\text { Egalitarian and } \\
\text { non-egalitarian }\end{array}$ & $\begin{array}{l}\text { Responsibility } \\
\text { of } \\
\text { independence }\end{array}$ & $\begin{array}{l}\text { Division of } \\
\text { work and } \\
\text { scientific } \\
\text { management }\end{array}$ & $\begin{array}{l}\text { Specialized } \\
\text { outsourced } \\
\text { network }\end{array}$ \\
\hline 2 & $\begin{array}{l}\text { Forecasting } \\
\text { and scheduling }\end{array}$ & $\begin{array}{l}\text { Exploration of } \\
\text { natural laws }\end{array}$ & $\begin{array}{l}\text { Informally } \\
\text { with human } \\
\text { considerations }\end{array}$ & $\begin{array}{l}\text { Formally in } \\
\text { tandem with } \\
\text { machine } \\
\text { schedules }\end{array}$ & $\begin{array}{l}\text { Project } \\
\text { management }\end{array}$ \\
\hline 3 & Designing jobs & - & $\begin{array}{l}\text { Agriculture as } \\
\text { process }\end{array}$ & $\begin{array}{l}\text { Fixed duty and } \\
\text { responsibility }\end{array}$ & $\begin{array}{ll}\text { Focus } & \text { on } \\
\text { objective } & \end{array}$ \\
\hline 4 & $\begin{array}{l}\text { Talent } \\
\text { acquisition }\end{array}$ & $\begin{array}{l}\text { Forbearing } \\
\text { outlook }\end{array}$ & $\begin{array}{l}\text { Frame of cast } \\
\text { system }\end{array}$ & $\begin{array}{l}\text { Darwinism, } \\
\text { rugged } \\
\text { individualism }\end{array}$ & $\begin{array}{l}\text { Capability to } \\
\text { produce }\end{array}$ \\
\hline 5 & $\begin{array}{l}\text { Time, } \\
\text { attendance and } \\
\text { absence } \\
\text { management }\end{array}$ & $\begin{array}{l}\text { Coordination } \\
\text { for egalitarian } \\
\text { benefits }\end{array}$ & Compensate & Clock & Productivity \\
\hline
\end{tabular}




\begin{tabular}{|c|c|c|c|c|c|}
\hline 6 & $\begin{array}{l}\text { Compensation } \\
\text { and benefits }\end{array}$ & $\begin{array}{l}\text { Quarry and } \\
\text { foodstuff, } \\
\text { appreciation of } \\
\text { family } \\
\text { members }\end{array}$ & $\begin{array}{l}\text { Produce of } \\
\text { choice }\end{array}$ & Exploitation & $\begin{array}{l}\text { Individual } \\
\text { equity and } \\
\text { compensation } \\
\text { objectives }\end{array}$ \\
\hline 7 & $\begin{array}{l}\text { Administration } \\
\text { of workforce }\end{array}$ & Imposition & Taking charge & $\begin{array}{l}\text { Force for } \\
\text { business interest }\end{array}$ & $\begin{array}{l}\text { Talent } \\
\text { management }\end{array}$ \\
\hline 8 & $\begin{array}{l}\text { Performance } \\
\text { management }\end{array}$ & Abysmal & $\begin{array}{l}\text { On the job } \\
\text { performance }\end{array}$ & $\begin{array}{l}\text { No link to } \\
\text { causation }\end{array}$ & $\begin{array}{l}\text { Culture of } \\
\text { performance }\end{array}$ \\
\hline 9 & $\begin{array}{l}\text { Career and } \\
\text { succession } \\
\text { planning }\end{array}$ & $\begin{array}{l}\text { Survival of the } \\
\text { fittest and } \\
\text { honing the } \\
\text { spirited } \\
\text { bloodline } \\
\end{array}$ & $\begin{array}{l}\text { Livelihood } \\
\text { and } \\
\text { civilization }\end{array}$ & $\begin{array}{l}\text { Scientific } \\
\text { utilization } \\
\text { resources }\end{array}$ & Collaboration \\
\hline 10 & $\begin{array}{l}\text { Learning and } \\
\text { training } \\
\text { management }\end{array}$ & - & $\begin{array}{l}\text { Imparting to } \\
\text { the next } \\
\text { generation }\end{array}$ & $\begin{array}{l}\text { Machine, } \\
\text { guidelines, and } \\
\text { checklists }\end{array}$ & $\begin{array}{l}\text { Knowledge } \\
\text { networks }\end{array}$ \\
\hline
\end{tabular}

Table 1: Workforce management areas and practices in different ages

Principles, values and practices are always inline, in case of any body - individual, organization or society. What one practices is the value and what one values is the principle. These practices are the first step towards deciphering of workforce management. For further insight, we may move down deeper to the values that caused certain practices, thus, recognizing what principles got cognizance in different times and, hence, may make a humble effort of anticipating the future trends of practices, values and principles.

\section{Conclusion}

The paper is much grounded effort of understanding and unfolding the times unseen. The exploration of workforce, management and workforce management, identified with ten functions: analysis of work, forecasting and scheduling, designing jobs, talent acquisition, time, attendance and absence management and benefits, administration of workforce (work and culture discipline), performance management, career and succession planning, and learning and training management, has been compared for four sections of time known with the existence of humanity. Here, also tried to unfold the information age, what is it, when it started and what its features are.

Exploring the practices of workforce management for the four ages gives data to be fathomed for understanding the brights and the darks, that can help to have discernment for future. No age suddenly appeared, it was the produce of preceding age. And the preceding age was not really responsible for what happened in succeeding age. It is evolutionary and it has deep traces to be explored till the end of time. 


\section{References:}

1. Industrial Revolution Overview. Youtube. Viewed 06/12/2013. Available at http://www.youtube.com/watch?v=d4joqYycnqM

2. Rodriguez, S. (2013). Amazon is not alone: UPS, Google also testing delivery drones. Los Angeles Times, 3 Dec.

3. Steiner, R. (1987). Polarities in the Evolution of Mankind. Great Britain: Whitstable Litho, Kent. p12

4. Management. BusinessDictionary.com. Viewed 06/12/2013. Available from http://www.businessdictionary.com/definition/management.html

5. Calvert, N. (2004). Gower Handbook of Call and Contact Center Management. England: Gower Publishing Limited. P 182

6. Workforce management. BusinessDictionary.com. Viewed 07/12/2013. Available at http://www.businessdictionary.com/definition/workforce-management.html

7. Bose, P. N. (1990). Civilization through the Ages. New Delhi: Mittal Publications. p 5-6

8. Albert, D. S. and Papp D. S. (1997). The Information Age: An Anthology on It's Impact and Consequences. CCRP Publication Series.

9. Humbert, M. (2007). Technology and Workforce: Comparison between the Information Revolution and the Industrial Revolution. University of California, Berkeley School of Information. $p 5$

10. Josh, $M$ in Media Future Conference 2012. Viewed 11/12/2013. Available on http://www.siliconrepublic.com/new-media/item/27296-harvard-business-review-pub

11. Humbert, M. (2007). Technology and Workforce: Comparison between the Information Revolution and the Industrial Revolution. University of California, Berkeley School of Information. $p 9$

12. Lee, R. B. (2005). Cambridge Encyclopedia of Hunter and Gatherers. Cambridge University Press. $p$ inside front cover.

13. Nolan, R. (2011). Creative Destruction of Industrial Age Management Principles and Creative Construction of Information Age Management Principles. June 11, 2011. A case study published by Harvard Business School. p 2

14. Ibid. $\mathrm{p} 9$

15. Turban, E and Volonino, L. (2010). Information Technology for Management. 2010. New Delhi: Wiley India (P) Ltd. p 13

16. Talent Acquisition. Recruiter.com. viewed 13/12/2013. Available: http://www.recruiter.com/i/talent-acquisition/ 